\title{
Development of the Education of Galician Jews at the Turn of THE 19Th aNd 20Th CENTuries as Exemplified by THE City OF Lviv
}

\author{
Mirosław Łapot \\ (iD) https://orcid.org/0000-0002-1773-8410 \\ (Jan Dlugosz University in Czestochowa, Czestochowa, Poland) \\ e-mail: m.lapot@interia.pl; m.lapot@ujd.edu.pl
}

Keywords: Jewish history, education, Galicia, Lviv

\begin{abstract}
In the 19th and at the beginning of the 20th century Galician Jews gradually left the isolated world of traditional culture for the open worldwide culture. At the start, they knew only one path of life, based on many centuries of tradition, but at the end it provided many paths to self-realization. Some of them were still devoted, other secular, some of them felt Jews, others felt Poles of Mosaic faith or Germans of Mosaic faith, some were involved in the Zionist movement, others in socialism. Many of them considered Galicia to be their own little motherland and manifested the features of local patriotism. It was possible thanks to the modernization of their lifestyle, and public education turned out to be one of the most important factors in this process. It was possible also thanks to the country authorities creating conditions which encouraged Jews to send their children to public school. Consequently, the majority of Jewish boys and girls completed compulsory education. It was the first step towards the modernization of their life.
\end{abstract}

\section{Introduction}

Historical and educational research into Jewish education, from the Enlightenment to the Holocaust, includes on the one hand secular education for Jews, and on the other the traditional model of religious education. In the second research pipeline, a view which emerged even before the Holocaust claimed that cheder and yeshiva were the source of Jewish exclusivism and an obstacle on the way to acculturation and assimilation. Traditional Jewish education has been rarely analyzed, and that has perpetuated this negative impression. It is only in recent years that works contradicting the stereotypical image of cheder and yeshiva have been published. ${ }^{1}$ However, the main subject of studies devoted to the education of Jews in Central and Eastern Europe (CEE) was, and is, the Jewish Enlightenment, the so-called Haskalah, and its impact on the traditional education model among Jews. The works of Eliav Mordechai, Shmuel Feiner, Britta L. Behm and Mordechai Zalkin should be mentioned here. ${ }^{2}$ The area of research is most often 19thcentury Prussia and The Pale of Settlement in Russia. It should be noted, however, that

\footnotetext{
1 About cheder see also: Assaf 2010: 111-130; Łapot 2014: 496-511.

2 See: Mordechai 2001; Feiner 2001; Feiner 2011; Feiner 2010; Behm 2002; Zalkin 2016.
} 
the first state to provide the Jewish population with compulsory education and create public schools was Austria.

Under the Habsburg monarchy there were two Jewish worlds, namely the world of Western Jews, emancipating themselves, speaking the language of the Christian environment, living mainly in the lands inhabited by indigenous Austrian, Bohemian and Moravian populations, and the world of the Galician Jews attached to Yiddish-speaking traditions. Galician Jews were distinguished from their co-religionists of Western Europe. Before the Enlightenment, they had enjoyed suitable conditions for preserving their own culture. It was based on religion, Torah and Talmud studies, and on preserving holidays and customs.

It seems to be interesting and necessary to show the education of Jews in Galicia, where two models of education, religious and secular, were confronted. This is an opportunity to analyze the functioning of the Jewish community in Lviv, a city described in Polish, Austrian, German and Ukrainian historiography as a place where different cultures meet. ${ }^{3}$ The color of the city, which was nationally and culturally diverse, was enhanced by the Jews. In the 19th and early 20th centuries, they represented various religious and political views, largely reflecting the dilemmas of the entire community throughout CEE. The analysis of the activity of Jewish residents of this city carries with it major research potential already noticed by many historians. ${ }^{4}$ The development of Jewish education in the capital city of Galicia was dealt with in my monograph. ${ }^{5}$ This paper refers to the findings contained therein, yet the main goal of it is to answer the question: How did the role of education develop, and what was it like in the modernization of Jews? The main epistemological interest lies in education as a catalyst and a mirror of political, social and cultural changes in the life of this minority in Lviv and Galicia. I attempt to show how the political, social and cultural changes in Galicia shaped the stages of developing public schools for Jews and the evolution of the attitude of Jews towards public education. This micro-history, based on the study of a small space (like a city), could be helpful to the historical understanding of Jewish life in the whole country and region in this period of time.

\section{Lviv Jewish community 1772-1918}

Galicia was the largest province of the Habsburg Empire, with a territory of almost 80,000 square kilometers and a population reaching 4 million at the beginning of the 19th century, while exceeding 8 million in 1914. The most important role was played there by three national groups: Polish, Ruthenians and Jews - see Table 1.

${ }^{3}$ Fässler, Held, Sawatzki (eds.) 1993; Mick 2015.

${ }^{4}$ Mendelsohn 1969: 577-590; Mendelsohn 1971: 521-534; Holzer 1993: 75-91; Gąsowski 1997; Holzer 1999: 79-85, Wierzbieniec 2000: 223-250, Manekin 2010: 121-130; Sroka 2018.

5 Łapot 2016. 
Table 1. Galician population $1825-1910$

\begin{tabular}{|l|l|l|l|c|}
\hline \multicolumn{1}{|c|}{ Year } & \multicolumn{1}{|c|}{ Poles } & \multicolumn{1}{|c|}{ Ruthenians } & \multicolumn{1}{c|}{ Jews } & Total \\
\hline 1825 & $1,800,000$ & $1,740,000$ & 270,000 & $3,850,000$ \\
\hline 1857 & $1,981,076$ & $2,085,431$ & 448,973 & $4,632,866$ \\
\hline 1880 & $2,706,977$ & $2,518,408$ & 686,596 & $5,938,461$ \\
\hline 1910 & $3,731,569$ & $3,379,613$ & 871,895 & $7,980,447$ \\
\hline
\end{tabular}

Source: Korduba 1926: 4-7.

The Jewish population in Galicia was the biggest of all the lands and kingdoms of Austria, and one of the biggest groups of the people of Mosaic religion in Europe. In literature Galicia is described as the "Jewish refuge" (Polish: "żydowski matecznik"), ${ }^{6}$ and Lviv as the Jewish mother city. ${ }^{7}$

Lviv was the important center of Jewish life in the First Polish Republic, and it played the same important role for this society under Austrian rule until 1918. As a capital city of a crown land in the 19th century and the beginning of the 20th, Lviv developed very intensively, and the population of the followers of Judaism grew along with it. In 1800, it was home to 18,000 Jews, and in 1869 approximately 27,000. In 1880, the 30,961 Jews constituted $28.1 \%$ of the city's population. Ten years later, the number of them grew to 36,130 , with their percentage remaining at an identical level (28.2\%). In 1910, 57,337 Jews lived in the city, and their percentage reached $29 \%$ of all inhabitants. ${ }^{8}$

The Galician Jewish community, including Lviv, was not homogeneous. Until the end of the 18th century, Jewish society had been dominated by Orthodox Judaism, but later, Hasidism won great popularity amidst the Jews of Podole, Volhynia and the Eastern territory of Galicia. The Haskalah, or Jewish Enlightenment, was the third, next to Orthodox and Hasidism, trend in the religious life of the Jews in Lviv and Galicia. ${ }^{9}$ At the end of 19th century, a new trend in the outlook of Jews appeared, that of Zionism. ${ }^{10}$ At the turn of the 19th and 20th centuries, a significant part of Jewish society was influenced by socialism. The ideas of the equality and brotherhood of all workers regardless of origin attracted, in particular, the Ostjuden, living in a cultural ghetto and treated as social outcasts. ${ }^{11}$

The political conditions: the Partitions of Poland, the social reforms of the Habsburgs, Napoleonic era, the Spring of Nations, the creation of Austria-Hungary and receiving autonomy by Galicia, and new social movements, namely the Haskalah, Zionism and socialism, initiated the changes in the outlook of Lvivian Jews and stimulated the process of emancipation in this conservative community. ${ }^{12}$ One manifestation of those

${ }^{6}$ MacCagg 2010: 45.

${ }^{7}$ Bartal, Polonsky 1999: 8.

${ }^{8}$ Cała 2000: 195-196; Gruiński 1910: table IV; Wasiutyński 1930: 128-129.

${ }^{9}$ Holzer 1999: 81.

${ }^{10}$ Rędziński 2000: 25.

11 Ibid.: 28.

${ }_{12}$ Wierzbieniec 2000: 223-250. Artur Eisenbach distinguished three models of this process (Eisenbach 1988). The first, American, had democratic features: the liberty of all citizens and their equal rights, proclaimed in 1776, meant full citizens' rights for the Jewish population. The second model, France, so-called 
changes was the attitude towards education. We have to be conscious that in Poland before the Partitions, Jews benefited only from the traditional educational system of cheders and yeshivas. In 1772-1918, in Lviv and throughout Galicia, many educational activities with the goal of assimilation and acculturation of the Jewish community took place. The following sections of this article show the stages of development of public schools for Jews and the evolution of the attitude of Jews towards public education in relation to political, social and cultural changes.

\section{Stage I - Hombergian schooling (1788-1806)}

The first stage was commenced at the end of 18th century by establishing GermanJewish schools, known as Hombergian schools. ${ }^{13}$ What were the circumstances of their appearance and activities?

During the reigns of Maria Theresa (1745-1780) and Joseph II (1780-1790), a new chapter in the history of Galician Jews opened. The empress imposed a special regulation on Jews in 1773 (Betteljuden, about poor Jews) forcing them to leave the country if they had problems paying a tolerance tax. In 1776, Maria Theresa established an autonomous office for Jewish matters, whose task was to organize the life of Jews on the Polish territories incorporated into Austria. In 1785, Emperor Joseph II abolished the rabbinical judiciary, imposed further taxes on Jews, and forced them to accept German surnames. ${ }^{14}$ The intention of the Austrian authorities was equality for the Jewish population, but, as Sv`atoslav Pacholkiv has written, the loss of communal autonomy (qahals) and the abolition of the rabbinical judiciary were the price of civic equality. ${ }^{15}$

In 1788, Joseph II became the first sovereign in Europe to introduce mandatory military service for Jews. He started working towards changing in the occupations of Jews, abolished the limitations in terms of trade and craft, and encouraged the development of Jewish farming. The Habsburgs' policy with regard to Jews resulted from the implementation of a project to create a well-educated and rich society of citizens who would be ready to benefit from the fruits of enlightened absolutism. It was necessary to abolish the complicated system of privileges and limitations, and to equalize all the inhabitants of the multicultural empire under the law.

In 1772, the Habsburgs imposed compulsory education on Jewish children. In 1787 , Josef II issued a decree which established separate public schools for Jews, with German as the language of instruction. The organizer of these schools was a colleague of Moses Mendelssohn, Herz Homberg (1749-1841) from the Czech Republic. Similarly

revolutionary, consisted in emancipation of Jews on the wave of citizens' liberties granted by Napoleons' Civil Code instead of cutting feudal ties. The third is the step-by-step, compromising, so-called Prussian model. Importantly for this paper, it was adopted in Austria as well. For A. Eisenbach the Jewish question is an integral element of the rebuilding of European countries. The progress in this matter was simultaneous (or occurring merely a little later) with the emancipation of townspeople and peasants.

${ }_{13}$ Polonsky 2014: 96; MacCagg 2010: 45.

${ }^{14}$ DALO, Fond 1, desc. 3, case 53, Dekret cesarza Józefa II o zrównaniu w prawach i obowiazkach Żydów Galicji z chrześcijanami.

${ }_{15}$ Pacholkiv 2011: 9; Grodziski 1994: 64-80. 
to Mendelssohn, he had graduated from a traditional Jewish institution of education and later received secular education. In Trieste, Homberg fulfilled the educational policy of the emperor, and he established the first German-Jewish schools in the Habsburg Empire. Being a maskil, he wanted to reform Judaism and prepare the young generation to participate in the social life of all citizens. It did not mean the abandonment of Judaism, but rather escape from the cultural ghetto. ${ }^{16}$

Homberg came to Lviv in 1788. During his rule, three secular schools for Jews were established in this city. In the Hombergian schools, Jews worked as teachers, and German was the language of instruction. The classes were conducted from Sunday to Friday, implementing the same curriculum as other schools and using the same textbooks. The curriculum subjects were writing and reading in German, counting, singing, calligraphy, and gymnastics. Homberg did not introduce Jewish religion as a school subject, ${ }^{17}$ leaving religious education to traditional cheders (see Figure 1).

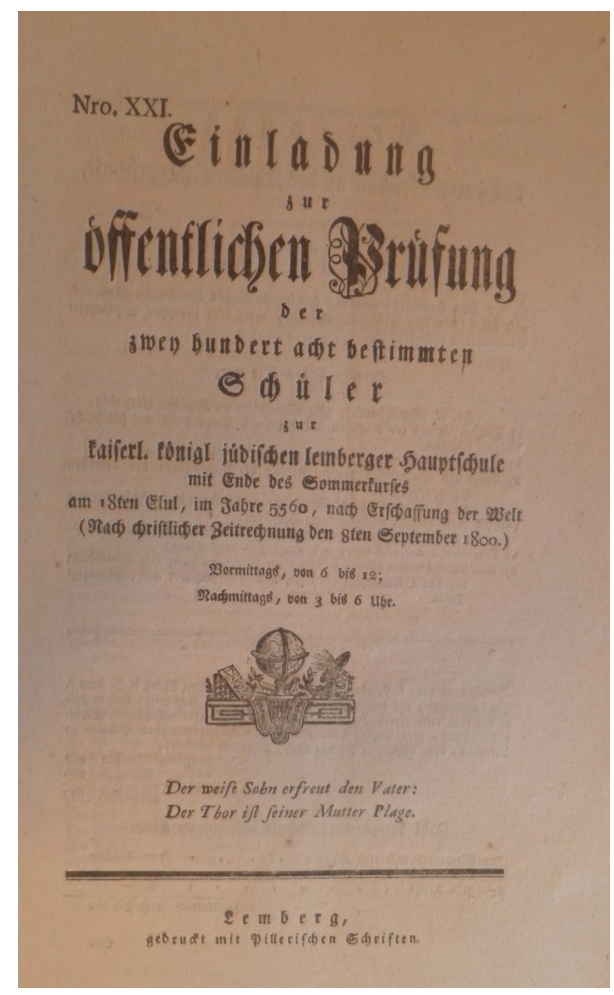

Figure 1. Invitation for a final exam of the summer term in the Jewish Main School in Lviv (Hauptschule). Source: CDIAL, Fond 146, desc. 66, case 1897, file reference no. 4; Einladung zur öffentlichen Prüfung der zwei hundert acht bestimmten Schuler zur kaiserl. königl. jüdischen klemberger Hauptschule mit Ende des Sommerkurses, Lemberg, [1800]: 4.

16 Bałaban 1920: 191-235; Adamczyk 1998: 47-55; Sadowski 2010. Some authors write about Trieste as a Jewish harbor of Haskalah in 18th century - Dubin 1999; Sorkin 1999: 87-97.

${ }^{17}$ Homberg was the author of the manual Bne Zion: Manekin 2011. 
In 1800 , there were 467 boys and 210 girls in all three schools. All the Jewish schools suffered from poor attendance. ${ }^{18}$

Within about 12 years Homberg had formed a school network for Jews throughout Galicia, counting 107 male elementary schools and a few female schools, with German as the language of instruction. Approximately 150 teachers worked in them, with 4,000 children as their pupils. ${ }^{19}$ This was insufficient, considering the entire population of 200 thousand people. Orthodox Jews were reluctant to take up secular education, considering it the first step to the abandonment of Judaism. Homberg, although a coreligionist, was treated like an apostate. Orthodox Jews felt the traditional cheder to be the best education option for Jewish children. There were 160 pupils in the biggest cheder in Lviv, but in total there were 85 cheders in the city area, compared to three secular schools attended by only 389 pupils. ${ }^{20}$

Shmuel Feiner wrote, "The eighteenth century is the time in which many Jews in Europe moved into the modern age." ${ }^{21}$ The acculturation of Jews was manifested in their dress, knowledge of German and French, and a modern lifestyle at the beginning of the 18 th century. Feiner provided instances from Berlin, Hamburg, Amsterdam, London, Metz, Bordeaux, The Hague, Vienna, and elsewhere, ${ }^{22}$ although the situation in Lviv and Galicia was diametrically opposite. Although in Hombergian schools religion and the moral difference of Jews was taken into account, and only Jews taught there, for the Orthodox they were excessively progressive. Homberg had to leave Lviv and Galicia, and the schools founded by him ceased to exist in 1806. The first attempt at establishing public schooling for Jews in Lviv and Galicia ended in failure, but it did provide a precedent for further attempts to establish secular education amongst the population of Orthodox Jews.

\section{Stage II - Israelite Folk School (1843-1914)}

After the fall of the Hombergian schools, only two secular Jewish schools were functioning in Galicia, in Tarnopol and Brody. Another similar school was established in Lviv in 1843. What was the reason for its creation, and was its fate the same as that of the Hombergian schools?

In 1842, Vienna nominated new management of the Jewish community in Lviv, consisting of Haskalah followers. Under the leadership of a new rabbi, Abraham Kohn, the management undertook reforms, and a part of them was the establishing of a modern folk school by the community. As soon as in 1843, Vienna agreed to form the Jewish-German Main School in Lviv (Lemberger deutsch-israelitische öffentliche Hauptschule). It was a four-class school for boys and girls with German as the language of instruction. It followed the curriculum of a secular folk school. To encourage Orthodox Jews to attend this

\footnotetext{
${ }_{18}$ CDIAL, Fond 146, desc. 66, case 1889, passim.

19 Eisenbach 1998: 264.

20 Rędziński 1997: 52.

21 Feiner 2007: 34.

22 See more: Feiner 2004.
} 
new type of school, Jewish religion and the Hebrew language were introduced as school subjects. They were the foundation of the education and upbringing plan. The school was financed by a special fund supported by taxes on kosher slaughter.

The school director, Rabbi Abraham Kohn, delivered sermons in the German language in the new synagogue, called Tempel, and promoted Jewish Enlightenment ideas. The Orthodox were not keen on him. He was persuaded to leave the city, and even threatened with death. Kohn continued with his reforms until 1848, when he was poisoned by one of the Hasids. ${ }^{23}$

The school, however, survived after Kohn's death. In the mid-19th century, 700 pupils were attending it, and the number of students was rising, so in 1855 another two secular schools for Jews were appointed by community, but they had a lower degree of organization (trivial school). Both of these schools segregated classes into male and female. In 1856, the three Jewish secular schools in Lviv were attended by approximately 1,000 children. ${ }^{24}$

How do we explain the different fates of secular schools for Jews at the turn of 18th and 19 th centuries, and in the mid-19th century? In the mid-19th century, Lviv became one of the major Haskalah centers in Galicia. Its precursor in the capital of Galicia was Juda Leib Mieses (1798-1831), a Lviv-born author of works criticizing the obscurantism and superstitiousness of orthodoxy. Another pioneer of the Haskalah was Solomon Judah Rappaport (1790-1867). Rappaport was born in Lviv, and later lived in Tarnopol, Brody and Prague. He was the first to subject biblical and rabbinic literature to scientific analysis. In Lviv lived the popular Hebrew satirist Izaak Erter (1791 [1792]-1851). The city was also visited by Nachman Krochmal (1785-1840), ${ }^{25}$ the most prominent of the Haskalah philosophers, called "the Mendelssohn of Galicia," and by Joseph Perl (1773-1839), the founder of the secular Jewish school in Tarnopol. ${ }^{26}$ Although the Rabbi A. Kohn, similarly to Homberg, met with the resistance of the conservative majority, he was supported by the Haskalah followers. More important than the activity of the modern Jewish elite was the attitude of the Jewish masses. The need for education and emancipation among the Jewish population was stronger than half a century before.

Jewish secular schools succeeded, but traditional Jewish education still existed and dominated. There are no documents about cheders in this period of time, but they must have been very numerous, because in the later 19th century the public education authorities took decisive action to limit their number. The first cheder census from 1874 provided official information about 71 cheders (the actual number must have been higher). The number of cheder pupils was certainly higher than the number of pupils in the three Jewish secular schools. Although individuals started to appear in junior high schools and universities, Jews were still on the margins of social life. The Haskalah was, therefore, attractive primarily to the elite..$^{27}$

\footnotetext{
23 Stanislawski 2007.

24 Łapot 2016: 92.

25 Allinson 2017: 127-139.

26 Manekin 2018: 61-71.

27 Holzer 1999: 81.
} 


\section{Stage III - The development of public schools for Jews in the Galician autonomy period (1867-1918)}

In 1867 Galicia obtained autonomy as an effect of the transforming of the Habsburg monarchy into the dual state of Austria-Hungary, and the liberalization of internal policy. Political reforms were aimed towards the equality of all inhabitants. The Galician Jewish community benefited from this policy as well, and started to participate in social, political and cultural life. ${ }^{28}$

The first Jewish societies and political parties were the expression of modernization. In 1870, Orthodox Jews established Machsike Hadas (Strengthening of Faith), and, at the beginning of 20th century, they founded the Aguda Israel Party. In 1883, Zionists founded the Mikra Kodesz Organization, transformed in 1888 into the Syjon Society. In 1892, in the capital of Galicia the first group of Jewish workers was established, to be followed in 1906 by the Żydowska Partia Socjalno-Demokratyczna (Jewish SocialDemocratic Party). Both Jewish nationalism and socialism offered Jews a new identity, and they found many supporters.

As well, in 1882 the Haskalah followers established the Association of Brothers (Polish: Przymierze Braci, Hebrew: Agudas Achim). They supported the idea of integration into Polish culture, but wanting to maintain their Jewish identity they popularized the idea of a Pole of Mosaic Faith, thus exposing themselves to criticism from the Orthodox milieu. ${ }^{29}$

In the autonomy epoch, Jews were no longer the passive recipients of reforms; they initiated changes and actively implemented them. A new Jewish elite emerged, one which competed with the orthodoxy for ideological leadership. They were the members of city councils and the chambers of trade and industry, and they benefited from the right to form associations and the opportunity to be educated in public schools and at universities. Many of them developed trade, economic and banking activities. Jews, even Orthodox Jews, started to take part in the political life of the country. They had the right to nominate candidates to run in elections to parliament in Vienna and to the national parliament. They were continuously represented in the State Council in Vienna, in the National Sejm in Lviv, and in the bodies of municipal authorities. In 1909, attorney Stefan Tobiasz Askenazy (1863-1920) became the vice mayor of Lviv (in the interwar period, the vice mayors were two other Jews who had grown up in Lviv in the era of autonomy, Filip Schleicher (1870-1932) and Wiktor Chajes (1875-1941)). Many Jews were actively involved in the life of the local community, for example, authorities serving in Lviv (among others Emil Byk (1845-1906) and Bernard Goldman (1841-1901)). Meir Balaban (1877-1942) and Moses Schorr (1874-1941), the co-founders of modern Jewish historiography, were born and educated in Lviv. The outstanding philosopher and religious scholar Martin Buber (1878-1965) grew up and was educated in Lviv from 1881 to 1897 . It was here where the Jewish press, art, literature and theater developed (the first permanent Yiddish theater was established in Lviv in 1888), along with sport,

\footnotetext{
28 The legal status of Jews in the Habsburg monarchy is explained in: Bartal, Polonsky 1999: 15-19.

29 Kapralska 2000: 191, 197; see also: Manekin 2010: 121-130; Kopff-Muszyńska 1992: 187-203.
} 
as two of the first gymnastic associations in the world, Dror and Makkabi, and the football club Hasmonea Lviv were formed there. ${ }^{30}$

Lviv became the home and the main center of the Haskalah in Galicia. ${ }^{31}$ Orthodox Jews and Hasids protested, but the maskilim continued their activity. In the first half of the 19th century, they assimilated into the German language and culture, but after 1867, in the epoch of Galicia autonomy, the Polish language and culture became closer to them. ${ }^{32}$ At the end of the 19 th century as the assimilation movement weakened, Zionism became more appealing to Jews. Nevertheless, both the supporters of assimilation and the Zionists stressed the importance of secular education for modernizing the lives of the masses. As a result, at the turn of 19 th and 20 th centuries, a sizeable Jewish intelligentsia formed: Galician Jews accounted for up to $58 \%$ of the total number of lawyers, $29.9 \%$ of doctors, and $17 \%$ of engineers. ${ }^{33}$

It seems legitimate to ask whether the colorful image of political, social and cultural life of Jews in this period is consistent with their educational capabilities. What changed in the educational system during this period? Did it allow Jews to modernize their lives or did it inhibit them?

In 1868, in Galicia the Land Education Council (LEC; Polish: Rada Szkolna Krajowa) was established, with headquarters in Lviv. It took over the supervision of elementary, secondary and vocational education. Schools with Polish or Ruthenian as the language of instruction, depending on the needs of the students, were established. The school law of 1872 imposed compulsory education on Jewish people as well. On the threshold of autonomy, cheder schooling was the fundamental form of the education of Jewish children in Galicia, but cheders did have the rights of public schools and could not provide a complete compulsory education. That opportunity was, as described in the previous chapter, provided by the secular schools of the Jewish community, although they could not admit all Jewish children at the age of compulsory education. ${ }^{34}$

Jews had to send their children to public, non-Jewish schools, and enlightened Jews did so without much hesitation, but for the Orthodox this option was not acceptable. They agreed only, and with much reluctance, to send their daughters to non-Jewish schools because they were not obligated to attend cheder or yeshiva, but their sons remained hidden in the cheders. Even fines and incarceration did not prove effective.

Orthodox Jews ignored public school in general, but surprisingly their attitudes towards the schools of the Jewish community formed by A. Kohn changed. They were secular like public schools, but the teachers were Jewish, and the special needs of followers of Mosaism were respected. The Orthodox regarded them as a lesser evil and a compromise solution. Attendance increased after the introduction of compulsory education to the extent that classrooms held up to one hundred pupils or more, but it was not

30 The best overview of the activity and accomplishments of Lviv Jews in the period of Galician autonomy is provided by Łukasz Tomasz Sroka in his monograph (Sroka 2018).

31 Rędziński 2000: 16.

32 Abraham Kohn was the first rabbi to preach in German in the 1840s, and Samuel Wolf Guttman was the first rabbi to preach in Polish at the turn of 19th and 20th centuries. Bussgang 1998: 127-153.

33 Rędziński 2000: 15-17; Holzer 1999: 79-85.

34 In Galicia in 1874, 16,137 Jewish boys and girls fulfilled the school obligation, slightly more than $20 \%$ of Jewish children at the age of compulsory education. In 1883, there were almost 40,000 Jewish pupils in public school; nevertheless, $50 \%$ of Jewish children did not complete compulsory education: Łapot 2016: 123. 
possible to admit every child. The authorities of the Jewish community appealed to the municipal council and to the LEC to subsidize forming new classes and the renting of new rooms to meet the needs of schools.

Considering the possibility of subsidized admission to Jewish schools, the members of the city council initiated establishing a new public school in Lviv where the special needs of Jewish children would be respected. It should be independent from the Jewish community and be under the supervision of the LEC. That plan was accepted by the city council, and in 1879 Tadeusz Czacki Folk School was opened. ${ }^{35}$ It was a public school, financed for land money, with Polish as the language of instruction, but, unlike in other public schools, religion and Hebrew classes were conducted as well. The pupils had a day off at the Sabbath time, and when the most important Jewish holidays were celebrated. The teachers were Jews, Poles and Ruthenians. The school was located in the predominantly Jewish district of the city, so up 100 percent of the students were Judaists.

School attendance was high, and two separate male and female schools were opened. In the first year of the male school's existence there were 196 pupils; in 1881 it was 293, and in 1882 as many as 431 . After ten years, the number of students was $667 .{ }^{36}$ The same held true in the female school. In the first year of activity (1879/1880), there were 236 girls enrolled, and two years later there were 680. After a decade, 752 Jewish girls were attending the school. ${ }^{37}$

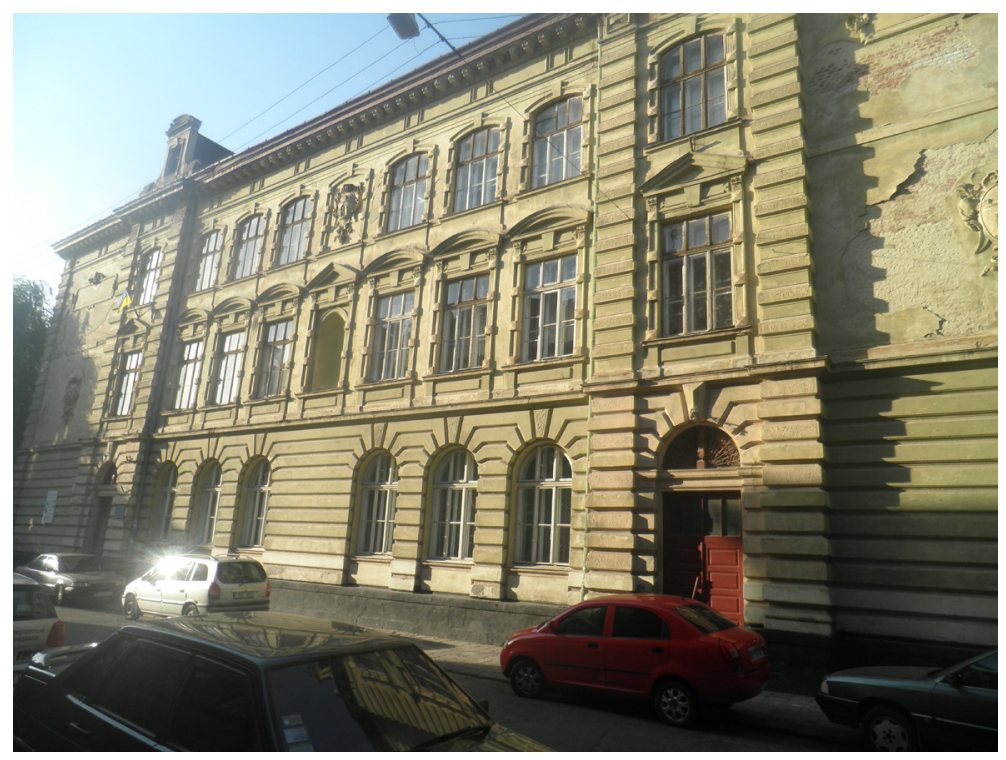

Figure 2. Tadeusz Czacki Folk School in Alembeków Street (today, Tamanska Street) - current view Source: Author's collection.

${ }^{35}$ Tadeusz Czacki (1765-1813) was a Polish politician and social activist, the director of the project of assimilation of Jews at the end of the 19th century.

${ }^{36}$ CDIAL, Fond 178, desc. 2, case 3713: 71.

${ }^{37}$ CDIAL, Fond 701, desc. 2, case 675: 106. 
Tadeusz Czacki School was the next stage on the way to making public education accessible to Jews. It persuaded Jews to attend public schools but was criticized in Polish national circles. City authorities were accused of funding "public cheders" with public money. The reason was that Czacki School was attended by Jewish students only, with no opportunities to integrate with non-Jewish pupils. After classes, they went back to their Jewish homes and districts, where only Yiddish, as the everyday language of the Jews, was spoken. It was claimed that assimilation would progress more rapidly if Jewish students had been attending schools of mixed nationalities and religions. This argument was taken into account by the city council, and schools exclusively for Jewish children were discontinued. There were special conditions in public schools giving opportunities to preserve the Mosaic faith and customs. If a school was attended by at least 20 followers of Judaism, Jewish religion classes were conducted, Jewish students had free time during Jewish holidays, and they were released from some school duties which ran counter to the rules of the Sabbath, such as writing. However, there were no Hebrew language classes, and the teachers were generally Christian. The most important difference in comparison to Czacki School was that the classes were non-denominational; students of different religions could sit down at the same school desk. This way, the influence of public school on Jewish children was strengthened. Consequently, Jewish students were seen in public schools. However, in none of them were they exclusive or did they form a simple majority, like in Czacki School (see Table 2).

Table 2. Boys and girls of the Mosaic faith in the public schools in Lviv in 1891/1892

\begin{tabular}{|l|l|l|c|c|c|c|}
\hline No. & School name & $\begin{array}{l}\text { Total } \\
\text { number } \\
\text { of stu- } \\
\text { dents }\end{array}$ & $\begin{array}{l}\text { Roman } \\
\text { Catholic }\end{array}$ & $\begin{array}{l}\text { Greek } \\
\text { Catholic }\end{array}$ & Protestant & Jews \\
\hline 1. & Saint Anne Male School & 574 & 390 & 57 & 1 & 105 \\
\hline 2. & Saint Anthony Male School & 345 & 264 & 50 & - & 16 \\
\hline 3. & Czacki Male School & 525 & - & - & - & 509 \\
\hline 4. & Empress Elisabeth Male School & 381 & 308 & 48 & - & 9 \\
\hline 5. & Konarski Male School & 208 & 158 & 32 & - & 18 \\
\hline 6. & Mickiewicz Male School & 430 & 276 & 44 & 2 & 97 \\
\hline 7. & Saint Mary Magdalene Male School & 428 & 323 & 69 & - & 16 \\
\hline 8. & Saint Martin Male School & 344 & 260 & 38 & 1 & 45 \\
\hline 9. & Piramowicz Male School & 290 & 179 & 28 & - & 83 \\
\hline 10. & Staszic Male School & 345 & 161 & 25 & 1 & 156 \\
\hline 11. & Saint Anne Female School & 768 & 532 & 69 & - & 145 \\
\hline 12. & Saint Anthony Female School & 369 & 290 & 25 & 2 & 41 \\
\hline 13. & Czacki Female School & 724 & - & - & - & 695 \\
\hline 14. & Empress Elisabeth Female School & 538 & 413 & 66 & 1 & 36 \\
\hline
\end{tabular}

Source: Baranowski 1895: 50. 
The growing influence of public school on the Jewish population is indirectly evidenced by a regression of traditional Jewish education. In 1874, there were 71 cheders; in 1881 there were 49 ; in 1889,51 ; in 1898,22 ; and in 1913, 22. It is known that 820 pupils were attending them in 1909, according to the official data. All the cheders met the sanitary-hygienic requirements. They were located on hired premises, and no longer in the private rooms of the melameds. Melameds had certificates which confirmed their qualifications. The efforts of educational authorities to take cheder schooling under control brought about a moderate success. The number of the cheders decreased, and the number of pupils in them as well. For the most traditional group of Jews, however, the cheder remained the fundamental form of education. ${ }^{38}$

\section{Conclusions}

Public schooling for the Jewish community of Lviv and Galicia was developed step by step. It is important that the Jewish community did not confine itself to obeying the decisions made by the authorities, as it was becoming more and more actively involved in the development of secular education. That process was initiated by the Haskalah, the Jewish Enlightenment, and the Habsburg reforms in the Austrian Empire. It was commenced by establishing the Hombergian (German-Jewish) schools at the end of 18th century, as one element of the more comprehensive program of the socialization of the Jewish population on the territories of Galicia, which was annexed by the Habsburg monarchy during the partition of Poland. Their organizer, Herz Homberg, failed. The Orthodox community did not accept changes to their traditional style of life.

The second stage was commenced by establishing, in 1843, a secular school for the followers of a particular confession, conducted by the Jewish commune in Lviv. It was conducted by an advocate of the Haskalah, Rabbi Abraham Kohn. Behind the success of this school lay the fact that in the middle of the 19th century Orthodox Jews were more likely to tolerate secular education. The cheder was still the center of religious upbringing, but some Orthodox Jews graduated from secular school, as well.

Kohn Folk School prepared the Jewish community for the next step, which they made in the period of Galician autonomy in the second half of 19th century. Making it possible was the establishment and development of public schools for Jewish children, supervised by the Land Education Council. Tadeusz Czacki Folk School, erected in 1879, was the first. The aim of this school was to more effectively integrate Jewish children into the surrounding Christian milieu. ${ }^{39}$

As a result, at the turn of the 19th and 20th centuries the Jews of Lviv had several options to fulfill their schooling duties in line with their worldviews. Orthodox Jews, treating public education as male necessare, sent their children to denominational schools, named after A. Kohn, which had the rights of the public schools. Conservative Jews, accepting the need to combine religious education with secular, chose T. Czacki, a public school but admitting only Jewish students. At the same time they also received religious

\footnotetext{
38 Łapot 2014: 500-511.

39 Łapot 2016: 507-508.
} 
education in cheders or from private teachers. Finally, liberal Jews striving for emancipation, which led to either assimilation, Zionism or Socialism, decided to educate their children in universally-accessible public schools. ${ }^{40}$

During the 19th century and at the beginning of the 20th, Jews emerged from the isolated world of their traditional culture into the opening worldwide culture. At the end of the 19th century, the Jewish masses were more likely to be interested in secular education, the maskils' milieu prepared an alternative model of education connecting limited religious knowledge with secular, and country authorities created conditions which encouraged Jews to send their children to public school.

\section{ABBREVIATIONS}

CDIAL - Central State Historical Archives of Ukraine in Lviv

DALO - State Archives of Lviv Oblast

\section{BIBLIOGRAPHY}

\section{Archival sources}

CDIAL

Fond 146, desc. 66, case 1897, Einladung zur öffentlichen Prüfung der zwei hundert acht bestimmten Schuler zur kaiserl. königl. jüdischen lemberger Hauptschule mit Ende des Sommerkurses [...] (Lemberg, [1800]).

Fond 178 , desc. 2, case 3713 .

Fond 701, desc. 2, case 675 .

DALO

Fond 1, desc. 3, case 53, Dekret cesarza Józefa II o zrównaniu w prawach i obowiqzkach Żydów Galicji z chrześcijanami.

\section{Secondary literature}

Adamczyk, M.J. (1998), Edukacja a przeobrażenia społeczności żydowskiej w monarchii habsburskiej 1774-1914, Wrocław.

Allinson, R.E. (2017), Nachman Krochmal and the Argument from Design, Scripta Judaica Cracoviensia, vol. 15: 127-139.

Assaf, D. (2010), "Small and Cozy"? The Song Oyfn Pripetshik and the Transformation of the Image of the Heder, in: The Heder: Studies, Documents, Literature and Memoirs, ed. D. Assaf and I. Etkes, Tel Aviv: 111-130.

Bałaban, M. (1920), Herz Homberg i szkoły józefińskie w Galicji (1787-1806). (Studium historyczne), in: idem, Z historii Żydów w Polsce. Szkice i studia, Warszawa: 191-235.

Baranowski, M. (1895), Historia szkót ludowych królewskiego stołecznego miasta Lwowa, Lwów.

Bartal, I., and A. Polonsky (1999), The Jews of Galicia under the Habsburgs, in: Polin. Studies in Polish Jewry, vol. XII: Focusing on Galicia: Jews, Poles, and Ukrainians 1772-1918, ed. I. Bartal and A. Polonsky, London-Portland, OR: 15-19.

${ }^{40}$ Such a situation in the Jewish Diaspora in Central and Western Europe occurred already in the mid19th century (von der Krone 2016: 66). The secular school was accepted among the Eastern Jews with much greater resistance. 
Behm, B.L. (2002), Moses Mendelssohn und die Transformation der jüdischen Erziehung in Berlin. Eine bildungsgeschichtliche Analyse zur jüdischen Aufklärnug im. 18. Jahrhundert, Münster-New York-München-Berlin.

Bussgang, J. (1998), The Progressive Synagogue in Lwów, in: Polin. Studies in Polish Jewry, vol. 11: Jewish Religious Life, 1500-1900, Liverpool: 127-153.

Cała, A. (2000), Lwów, in: A. Cała, H. Węgrzynek, G. Zalewska, Historia i kultura Żydów polskich. Stownik, Warszawa: 195-196.

Dubin, L. (1999), The Port Jews of Habsburg Trieste. Absolutist Politics and Enlightenment Culture, Stanford.

Eisenbach, A. (1998), Emancypacja Żydów na ziemiach polskich 1785-1870 na tle europejskim, Warszawa.

Fässler P., T. Held, and D. Sawitzki (eds.) (1993), Lemberg - Lwów - Lviv. Eine Stadt im Schnittpunkt europäischer Kulturen, Köln-Weimar-Wien.

Feiner, S. (2004), The Jewish Enlightenment, trans. Ch. Naor, Philadelphia.

Feiner, S. (2007), On the Threshold of the "New World" - Haskalah and Secularization in the Eighteenth Century, Simon-Dubnow-Institut Jahrbuch-Yearbook 6: 33-45.

Gąsowski, T. (1997), Między gettem a światem. Dylematy ideowe Żydów galicyjskich na przełomie XIX i XX wieku, Kraków.

Grodziski, S. (1994), Stanowisko prawne Żydów w Galicji: reformy Marii Teresy i Józefa II (17721790), in: Lud żydowski w narodzie polskim, ed. J. Michalski, Warszawa: 64-80.

Gruiński, S. (1910), Materiały do kwestii żydowskiej w Galicji, Lwów.

Holzer, J. (1993), Vom Orient die Fantasie, und in der Burst der Slawen Feuer... Jüdisches Leben und Akkulturation in Lemberg des 19. und 20. Jahrhunderts, in: Lemberg - Lwów - Lviv. Eine Stadt im Schnittpunkt europäischen Kulturen, ed. P. Fässler, T. Held, D. Sawatzki, Köln-Weimar-Wien: 75-91.

Holzer, J. (1999), Enlightenment, Assimilation, and Modern Identity: The Jewish Elite in Galicia, in: Polin. Studies in Polish Jewry, vol. 12, Focusing on Galicia: Jews, Poles, and Ukrainians 17721918, ed. I. Bartal, A. Polonsky, London-Portland, OR: 79-85.

Kapralska, Ł. (2000), Pluralizm kulturowy i etniczny a odrębność regionalkkna Kresów poludniowowschodnich w latach 1918-1939, Kraków.

Kopff-Muszyńska, K. (1992), Ob Deutsch oder Polnisch - przyczynek do badań nad asymilacją Żydów we Lwowie w latach 1840-1892, in: The Jews in Poland, vol. 1, ed. A.K. Paluch,. Kraków: 187203.

Korduba, M. (1926), Rozvii ukrains 'koho naselennia v Halychyni za ostannikh sto lit, Svit 15: 4-7.

Von der Krone, K. (2016), Old and New Orders of Knowledge in Modern Jewish History, trans. D.B. Lazar, Bulletin of the GHI 59, Fall: 59-82.

Łapot, M. (2014), Chedery lwowskie w okresie autonomii galicyjskiej (1867-1914), Jewish History Quarterly, no. 3(251): 496-511.

Łapot, M. (2016), Szkolnictwo żydowskie we Lwowie 1772-1939, Częstochowa.

MacCagg, W.O. (2010), Dzieje Żydów w monarchii habsburskiej w latach 1670-1918, trans. A. Szymański, Warszawa.

Manekin, R. (2010), The Debate Over Assimilation in Late Nineteenth-Century Lwów, in: Insiders and Outsiders. Dilemmas of East European Jewry, ed. R.I. Cohen, S. Hoffman, Oxford-Portland: 121-130.

Manekin, R. (2011), The Moral Education of Jewish Youth: The Case of Bne Zion, in: The Enlightenment in Bohemia: Religion, Morality and Multiculturalism, ed. I. Cerman, R. Krueger and S. Reynolds, Oxford: 273-294.

Manekin, R. (2018), From Johann Pezzl to Joseph Perl: Galician Haskalah and the Austrian Enlightenment, in: Jews and Germans in Eastern Europe: Shared and Comparative Histories, ed. T. Grill, Munich: 61-71. 
Mendelsohn, E. (1971), From Assimilation to Zionism in Lviv: The Case of Alfred Nossig, The Slavonic and East European Review 49: 521-534.

Mendelsohn, E. (1969), Jewish Assimilation in Lviv: The Case of Wilhelm Feldman, Slavic Review 28, no. 4: $577-590$.

Mick, C. (2015), Lemberg-Lwów-Lviv, 1914-1947: Violence and Ethnicity in a Contested City, Purdue.

Mordechai, E. (2001), Jüdische Erziehung in Deutschland im Zeitalter der Aufklärnung und Emanzipation, [I ed. Jerusalem 1960], Übers. M. Strobel, Münster-New York-München-Berlin.

Pacholkiv, S. (2011), Gminy żydowskie w Galicji w latach 1772-1848. Zagadnienia badawcze, in: Galicja 1772-1918. Problemy metodologiczne, stan i potrzeby badań, vol. 2, ed. A. Kawalec, W. Wierzbieniec, L. Zaszkilniak, introd. J. Maternicki, Rzeszów.

Polonsky, A. (2014), Dzieje Żydów w Polsce i Rosji, trans. M. Wilk, Warszawa.

Rędziński, K. (1997), Fundacyjne szkolnictwo żydowskie w Galicji w latach 1881-1918, Częstochowa.

Rędziński, K. (2000), Żydowskie szkolnictwo świeckie w Galicji 1813-1918, Częstochowa.

Sadowski, D. (2010), Haskala und Lebenswelt. Herz Homberg und die jüdischen deutschen Schulen in Galizien 1782-1806, Göttingen.

Sorkin D. (1999), The Port Jew. Notes Toward a Social Type, Journal of Jewish Studies 50, no. 1: 87-97.

Sroka, Ł.T. (2018), In the Light of Vienna. Jews in Lviv - between Tradition and Modernisation (18671914), Berlin-Bruxelles-New York-Oxford-Warszawa-Wien.

Stanislawski, M. (2007), A Murder in Lemberg: Politics, Religion, and Violence in Modern Jewish History, New York.

Wasiutyński, B. (1930), Ludność żydowska w Polsce w wiekach 19 i 20. Studium statystyczne. Warszawa: Wydawnictwo Kasy im. Mianowskiego, Instytut Popierania Nauki.

Wierzbieniec, W. (2000), The Process of Jewish Emancipation and Assimilation in the Multiethnic City of Lviv during the Nineteenth and Twentieth Centuries, Harvard Ukraine Studie 24: 223-250.

Zalkin, M. (2016), Modernizing Jewish Education in Nineteenth Century Eastern Europe School as the Shrine of the Jewish Enlightenment, Brill. 
